\title{
The Effect of Pindan Gonnung Traditional Game Toward Cognitive and Rough Motoric Development in Kindergarten
}

\author{
Wedya Puspita, Wahyu Sukartiningsih, Andi Mariono \\ Universitas Negeri Surabaya \\ Surabaya, Indonesia \\ wk7285@gmail.com
}

\begin{abstract}
This research aims to test the effect of "Pindan Gonnung" traditional game toward cognitive and rough motoric development in Kindergarten. This research used experimental with pretest and posttest control group design. The results show that the "Pindan Gonnung" traditional game is one of the games that can improve children's cognitive and rough motoric development and can preserve the local cultural heritage that has begun to disappear. Based on this result, it can be concluded that "Pindan Gonnung" traditional game give a insignificant impact on cognitive and rough motoric development in Kindergarten.
\end{abstract}

Keywords: traditional, pindan gonnung, development

\section{INTRODUCTION}

A game is one of the best strategies to develop children's cognitive and motor abilities in accordance with the competencies set out in the curriculum of early childhood in 2013. According to [1] in his journal with the title Interventions to Promote Physical Activity in Young Children, it is important to give a stimulation of gross motor development in early childhood. Through the game, children will acquire and proces the information, learn new things and train existing skills. [2] state that "game is important for early childhood education physical activity. It is essential to their development because it contributes to the cognitive, physical, social, and emotional well being of children and youth". It clearly means that a game will play a major role in the child's cognitive, physical, social and emotional development.

The game is one that allows children to develop a cognitive and physical motor. This activity is able to stimulate interest and ease them in learning. [3] defined a game as an activity that is done by using or without using tools that generate understanding, provide information, give pleasure and can develop children's imagination.

A game is a child's world. Game can meet the needs of children to be actively involved with the environment, to play and work in producing something, as well as to fulfill other cognitive development tasks. During the game, children receive new experiences, manipulate materials and tools, interact with others and begin to feel their world [4]. The results of The Smithsonian Institute explained that in Early Childhood Education (PAUD) learning is most effective technique through a concrete and game-oriented approach. Docket and Fleer [5] that a game is a necessary for children because through playing children will gain knowledge that can develop his ability, can be actively involved with the environment. During the game, children also receive new experiences, manipulate materials and tools, interact with others and begin to feel their world. Gross motor skills have been linked to several cognitive impairments related to learning speed and children's memory. This is because physical activity causes connections (synapses) between brain cells and whole brain organization [6]. This is reinforced by research conducted by [7] that conclude the motor development is related to the cognitive development of children so that children can learn faster through the game.

Children develop feelings about who they are and what is important in the cultural context. Traditionally the children's family and the cultural community spread the values, hopes, and ways of doing things that exist in life [8]. Based on this explanation, children's behavior is strongly influenced by their internal behavior and environment. Both of these are inseparable because the learning process takes place in the context of the interaction between the children's themselves and their environment.

Pindan Gonnung game is an activity that bring the traditional game context that has been left by children today. The Pindan Gonnung game is modified using a large-scale banner as a media, and the flannel number as a medium. Children play the game by jumping in accordance with the rules of Pindan Gonnung game and for children who can reach the top of the ladder of the Bromo crater, have to take one digit from the flannel randomly and store it. The, the child will be called by the teacher to stand in order in accordance with the number that has been taken, so the game is named Pindan Gonnung.

Pindan Gonnung Traditional Games is very concerned on the needs of children in accordance with its holistic development by involving them to be active in the learning 
process both cognitive and rough motor. For that, the activities include digging, counting the concept of numbers and not easily give up so that children can apply the learning acquisition to solve real problems in everyday life.

Through the game, children will be more enthusiastic to learn in a very fun way. Through the Pindan Gonnung Game, children will be able to rank the symbols of number and train their memory. The concept of the game is reinforced by the Behaviorist theory [9] that developed by Edwin Ray Guthrie as a Contiguity Theory. According to Edwin Ray Guthrie (Hitipeuw, 2009: 18-21) stated that learning is a consequence of an association (similarity) between a particular stimulus and response. Pindan Gonnung Traditional game is quite easy to do by children because it is done with the method that has become their characteristic and all the scope of development can be stimulated appropriately. It is expected that this game can be used as an alternative tools as a means of fun learning for early childhood, especially in kindergarten.

\section{METHOD}

This research entitled "The Effect Of Game Traditional "Pindan Gonnung" Toward Cognitive And Rought Motoric Development In Kindergarten" using a quantitative research approach with the experimental method. According to [10], quantitative research is a research approach that many are required to use numbers, ranging from data collection, interpretation of the data and the appearance of the results.

This research uses experimental shape experimental design experimental design with pretest and posttest control group design. According to [11] is said to be true experimental (experimentally true) because, in this design, researchers can control all the outside variables that affect the course of the experiment. The main feature of true experimental is that the samples used for the experimental group or control group are taken randomly from a specific population.

The population in this study were all children of group B in Ika Karya Bhakti Kindergarten, Maron Sub-District, Probolinggo District, East Java.

\section{RESULTS AND DISCUSSION}

This research uses ANOVA data analysis technique (Analysis of Variance). Anova is used to test the comparative hypothesis of two average samples if the data is in the form of intervals and ratios. Anova classification double / two way is used because each sample consists of two or more categories. A hypothesis test is divided into two, namely a one-way anova test and Manova test. One way anova test is used to test hypotheses 1 and 2, whereas the Manova test is used to test hypothesis 3 .

The data on the early observation of the children's cognitive development obtained the highest score 12, the lowest score 4 with the mean score of 8.93. The image of data observation as follows:

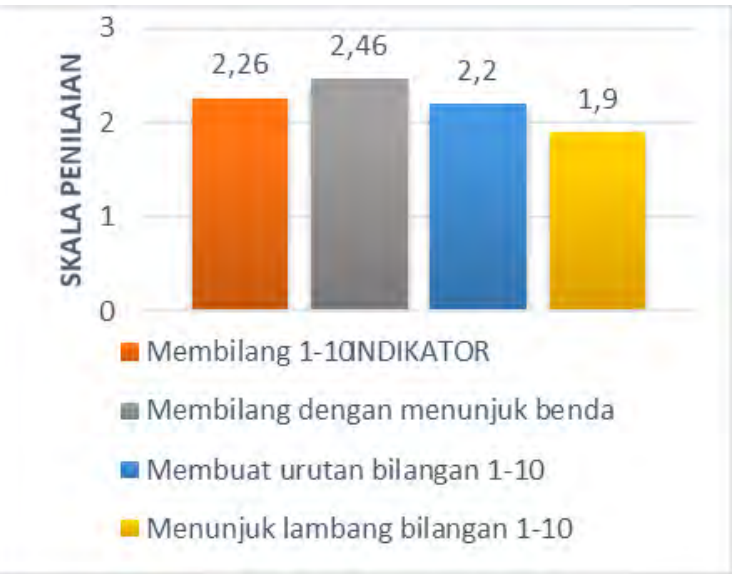

Figure 4.1. The data histogram of the children's Cognitive Development Before Experiment.

The data on children's cognitive development after the treatment obtained the highest score 16 , the lowest score of 10 and mean score of 12.93. The image of post-experimental observation as follows:

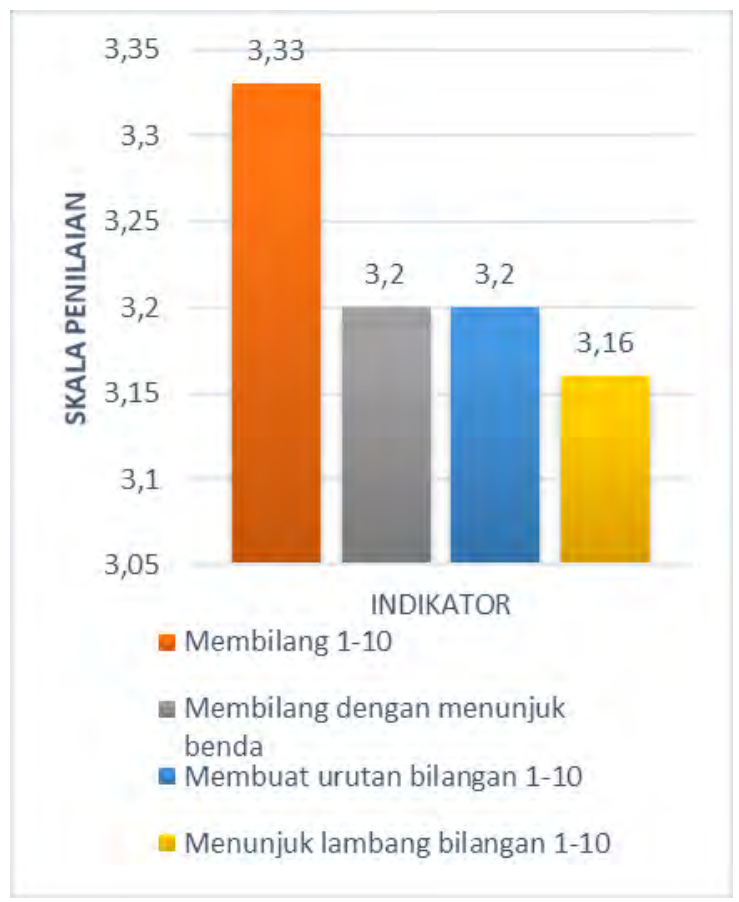

Figure 4.2. Histogram Data of the children's Cognitive Development after the Experiment.

Initial observation data of children's gross motor development obtained the highest score 10, lowest score 3 and mean score of 7.86. The image of observation data before the experiment as follows:

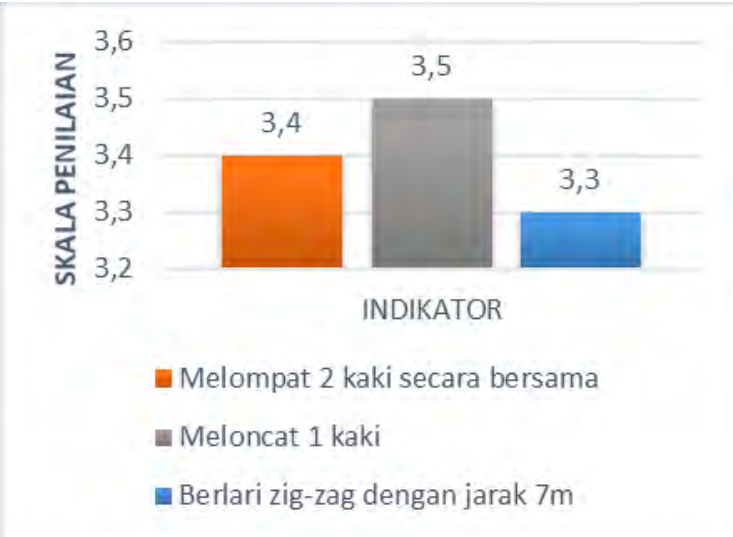


Figure 4.3. Histogram Data on children's Rough Motor Development of Children Before Experiment.

Rough motor development data after the experiment obtained the highest score of 12 , the lowest score of 9 and mean score of 10.26. The image of post-experimental observation as follows:

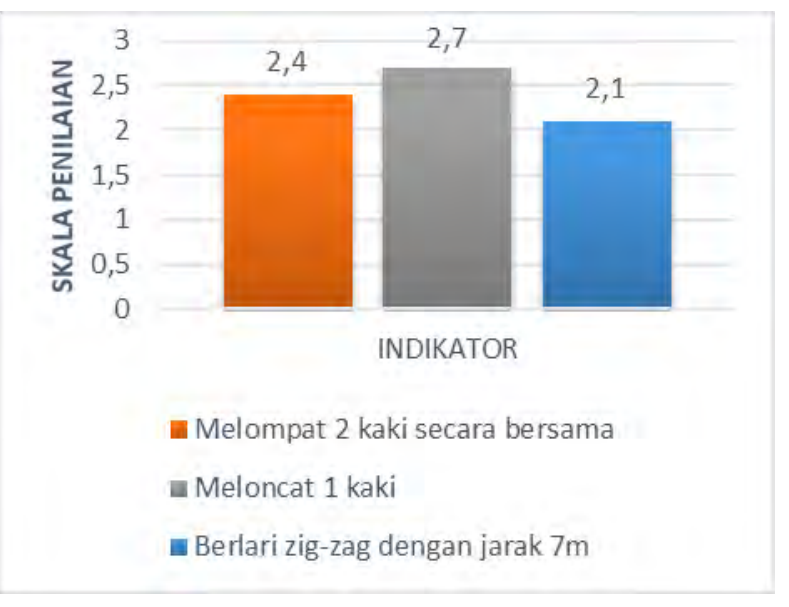

Figure 4.4. Histogram Data for children's Rough Motor Development of Children After Experiment.

Observations were conducted to determine the effect of traditional games on children's cognitive and motor development on group B PKK Ika Karya Bhakti in the 2017/2018 Academic Year. The result of the observation shows that the average final observation score is 12.9333 $($ mean $=12.9333)$ while the average initial observation score is $8.9333($ mean $=8.9333)$, so the difference of mean score value is 4.000 . While the results of rough motor observations of the average final observation score of $10.2666($ mean $=10.2666)$ while the average initial observation score of 7.8666 (mean = 7.8666), so the difference of the average score is 2.4 . This means that there is an influence of the Pindan Gonnung traditional game to children's cognitive and motor development. This is because the final observation score is higher than before the treatment was given. The improvement of their cognitive and motor development was caused by the activities that inviting children to play interesting traditional games. Then in this activity, children will perform activities according to indicators that have been set so that every children can play the game. In the final activities, it was conducted a discussion, question, and answer and review about the game that has been done. Gonnung is one of the traditional games that can develop a rough motor child through jumping activity. Jumping is done using one legs only when jumping and two legs at the time of the landing. At the time of going to jump, children is very careful to avoid the risk of injury. The role of both hands is very important as a counterweight at the time of the landing. Based on the above opinion the researcher understands that the traditional game is a game that can develop children's rough motor through jumping activities with one foot, since in the Pindan Gonnung traditional game there is the principle of experiential learning (learning experience directly). According to the results of preliminary and experimental observations, it is seen that almost all children of Ika Karya Bhakti Probolinggo PKK Kindergarten have a significant development in their rough motor. Pindan Gonnung traditional game that can stimulate the development of the child's motor is done individually but involves the role of friends in the game so that children is required to be able to discuss and communicate with his friends and be able to recognize the symbol of numbers, recognize the concept of numbers, sorting numbers and pointing symbols $1-10$. This supports the hypothesis that the Pindan Gonnung traditional game has an effect on children's cognitive and motor development in PKK Ika Karya Bhakti Probolinggo.

\section{CONCLUSION}

Based on the observations of the research results it obtained the Cognitive development data that the average final observation score of 12.9333 (mean $=12.9333$ ) while the average initial observation score of $8.9333($ mean $=8.9333)$ so there are differences in the mean values as 4.000 . While the results of rough motor observations made the average final observation score of 10.2666 (mean $=10.2666)$ while the average initial observation score of $7.8666($ mean $=7.8666)$ so there is a difference in average score of 2.4. Which means there is a significant influence of the Pindan Gonnung traditional game to children's cognitive and motor development. Thus, the tested hypothesis is accepted.

\section{References}

[1] S. G. Trost, "Interventions to promote physical activity in young children,” Phys. Act., p. 25, 2011.

[2] D. Strok, "Our 2008 reviewers [reviewer thanks]," IEEE Softw., vol. 26, no. 2, p. 4-pp, 2009.

[3] N. A. Wiyani, "Barnawi. 2012," Format Paud.

[4] Y. N. Sujiono, "Konsep dasar pendidikan anak usia dini," 2009.

[5] Y. N. Sujiono and B. Sujiono, "Bermain kreatif berbasis kecerdasan jamak," Jakarta Indeks, 2010.

[6] C. Gabbard, "Windows of opportunity for early brain and motor development," J. Phys. Educ. Recreat. Danc., vol. 69, no. 8, pp. 54-55, 1998.

[7] M. Barbu-Roth, D. I. Anderson, A. Desprès, J. Provasi, D. Cabrol, and J. J. Campos, "Neonatal stepping in relation to terrestrial optic flow," Child Dev., vol. 80, no. 1, pp. 8-14, 2009.

[8] J. L. Roopnarine and J. E. Johnson, "The Socio-Cultural Contexts of Early Education in Caribbean Societies," in Transitions to Early Care and Education, Springer, 2011, pp. 163-175.

[9] I. Hitipeuw, "Belajar \& Pembelajaran," Univ. Negeri Malang, 2009.

[10] S. Arikunto, Prosedur penelitian: Suatu pendekatan praktik. Rineka Cipta, 1992.

[11] Sugiyono, Metode penelitian pendidikan:(pendekatan kuantitatif, kualitatif dan $R \&$ D). Alfabeta, 2008. 